\title{
Ekmek Üretiminde Farklı Turunçgil Aldebolarının Kullanım İmkanları
}

\author{
Mustafa Kürşat DEMIR ${ }^{1}$, Nezahat OLCAY2 \\ Necmettin Erbakan Üniversitesi Mühendislik ve Mimarlık Fakültesi Gıda Mühendisliği Bölümü, Meram Konya/Türkiye \\ ${ }^{1}$ https://orcid.org/0000-0002-4706-4170, ${ }^{2}$ https://orcid.org/0000-0003-3302-8969 \\ 凹: mkdemir@erbakan.edu.tr
}

\begin{abstract}
ÖZET
Turunçgil kabukları atık olarak görülse de, özellikle albedo kısmı, ihtiva ettiği lif içeriğiyle gıda endüstrisinde değerlendirilebilme potansiyeline sahip bir yan ürün olarak karşımıza çıkmaktadır. Bu çalışmada; üç farklı narenciyeden (portakal, limon ve mandalina) elde edilen albedolar kurutulup öğütülmüş ve buğday ununa beş farklı oranda $(\% 0,2.5,5,7.5$ ve 10) ikame edilerek ekmek üretiminde kullanılmıştır. Albedo ikame oranı arttıkça örneklerin hacim ve spesifik hacim değerlerinin azaldığı, sertlik değerinin ise $\operatorname{arttığı~tespit~}$ edilmiştir. Ayrıca, tüm örneklerin kabuk ve iç dokularının $L^{*}$ değerlerinin azaldığı, $a^{*}$ ve $b^{*}$ değerlerinin ise arttığı görülmüştür. Artan albedo ikamesi, ham kül ve lif içeriğinin de artmasına neden olmuştur. Sonuçta; ekmek örneklerinin teknolojik özelliklerinin geliştirilmesi açısından turunçgil albedosu ikamesinin yapılması uygun bulunmuştur.
\end{abstract}

\section{The Usage of Different Citrus Albedos in Bread Production}

\begin{abstract}
Although citrus peels are seen as waste, especially the albedo portion appears a by-product with the potential to be used in the food industry with its fiber content. In this study; the albedos obtained from three different citrus fruits (orange, lemon and mandarin) were dried, grounded and used in bread production by substituted to wheat flour with five different rates $(0,2.5 .5,7.5$ and $10 \%)$. It has been determined that samples' volume and specific volume were decreased and the hardness value was increased with the increased albedo substitution. Also, it was observed that the $L^{*}$ values were decreased and the $a^{*}$ and $b^{*}$ values were increased of all samples' crust and crumb. Increased albedo substitution also caused an increase in raw ash and fiber content. In conclusion, it has been found appropriate the substitution of citrus albedos for improving the technological features of bread samples.
\end{abstract}

\section{Araştırma Makalesi}

Makale Tarihçesi

Geliş Tarihi : $: 30.04 .2020$

Kabul Tarihi : 18.06 .2020

\section{Anahtar Kelimeler}

Turunçgil

Albedo

Ekmek

Selüloz

Beslenme
Research article

$\begin{array}{ll}\text { Article History } \\ \text { received } & : 30.04 .2020 \\ \text { accepted } & : 18.06 .2020\end{array}$

Keywords

Citrus

Albedo

Bread

Cellulose

Nutrition

To Cite : Demir MK, Olcay N 2020. Ekmek Üretiminde Farklı Turunçgil Aldebolarının Kullanım İmkanları. KSÜ Tarım ve Doğa Derg 23 (6): 1545-1553. DOI: 10.18016/ksutarimdoga.vi.730246.

\section{Gỉî̧̧̇}

Beslenme; insanlarm hem sosyal ve fiziksel fonksiyonlarını sürdürmeleri hem de sağllğ̆ koruyup geliştirmeleri için gerekli olan besin ögelerini, yeterli miktarda ve uygun şekilde alması olarak tanımlanabilmektedir. Bu bağlamda, besleyici ve güvenli gıdaların toplum tüketimine sunulması, gıda üretiminin temel amacı olarak görülebilmektedir (Kaya, 2018; Mete ve Altıner, 2018).

Gelişen gida teknolojisi, tüketicilerin bilinçlenerek hayat beklentilerinin artmasına ve obezite başta olmak üzere artan sağlık sorunları nedeniyle sağllklı beslenme bilincinin oluşmasına yol açmış, dolayısıyla gıda ürünlerinin kalitesinin artırılması için yapılan çalışmalarla beraber fonksiyonel gıda üretim ve tüketimini artırmıştır. Gıdaların besleyici özelliklerinin yanı sıra sağlık üzerinde de olumlu etkiler sağlaması adına, güncel teknolojik uygulamalarla, yeni besin ögelerinin sağlanması için fonksiyonel gidalar alanında pek çok çalışma yapılmaktadır (Halaç, 2002; Meral ve Doğan, 2009; Aktaş, 2012). "Fonksiyonel gida" olarak tanımlanan gıdalara örnek olarak; düşük kalorili, lif içeriği artırılmış, düşük sodyumlu, glutensiz, probiyotik ve diyabetik gidalar gösterilebilmekte; fonksiyonel özellikler ise diyet lif, vitaminler, omega-3, 
flavonoidler ve bakteri kültürleri gibi bileşenlerin eklenmesi ile sağlanmaktadır (Boyacıŏlu, 2012; Şimşek ve ark., 2017).

Son yıllarda önemi gitgide artan fonksiyonel gıda bileşenleri olan diyet lifler; ince bağırsakta sindirilemeyen, kalın bağırsakta fermente olan, nişasta olmayan polisakkarit türevleri olarak tanımlanabilir (Harris ve Ferguson, 1999; Mete ve Altıner, 2018). Suda çözünen ve çözünmeyen olarak ikiye ayrılan diyet liflerin sağlık üzerindeki olumlu etkileri arasında; kolon kanserine karşı koruyucu olmasi, gastrointestinal sistemin normal fonksiyonunu devam ettirmesi, obezite, tansiyon, hemoroit, diyare, hipertansiyon, kalp-damar ve bağışıklık sistemi hastalıklarına iyi gelmesi sayllabilmektedir (Fernandez-Gines ve ark., 2001; Ekici ve Ercoskun, 2017; Mete ve Altıner, 2018). Sağlık üzerindeki olumlu etkileri nedeniyle hem diyet liflere hem de diyet liflerce zengin gidalara artan ilgi ile beraber; ekmek, makarna ve bisküvi gibi tahıl ürünlerinin de lifçe zenginleştirilmesi gündeme gelmiş, bu amaç doğrultusunda tahıl ürünlerine kepek fraksiyonları eklenmiştir. Fakat tahıl kepeklerinin gerek bileşimindeki fitik asit gibi antibesinsel faktörler, gerekse ürünlerdeki kalite ve duyusal parametreler üzerindeki olumsuz etkileri, yeni lif kaynaklarının araştırılmasına önayak olmuş, yapılan araştırmalar sonucunda ise meyve ve sebzelerin de zenginleştirilmede kullanılabilecek diyet lifçe zengin kaynaklar olduğu görülmüştür (Garcia-Estepa ve ark., 1999; Türksoy, 2011).

Turunçgiller Rutaceae familyasının Aurantoideae alt familyasındaki Citrus cinsine ait olan, anavatanı tropik ve subtropik iklimlerin hakim olduğu; Çin, Güneydoğu Asya ve Hindistan olan, ağaççık şeklindeki iki çenekli bitkilerdir (Kaygısız ve Aybak, 2005; Liu ve ark., 2012; Cin ve Gezer, 2017). Dünyada yaygın olarak tarımı yapılan turunçgil çeşitleri; portakal ( $C$. Sinensis), mandalina (C. Reticulata), turunç ( $C$. Aurantium), limon (C. Limon), misket limon ( $C$. aurantifolia), pomelo ( $C$. Maxima), greyfurt $(C$. paradisı) ve bergamot (C. Bergamia) olarak sıralanabilir (Mendilcioğlu, 1996; Kaygisız ve Aybak, 2005; Cin ve Gezer, 2017). 2015 yll itibari ile Türkiye'deki turunçgil türleri üretimin oranları sırasıyla; portakal için \%45.7, mandalina için \%29.0, limon için \%18.8 ve greyfurt için \%6.3 şeklindedir (TÜİK, 2016). Turunçgiller; C vitamini, niasin, folik asit, kalsiyum, potasyum, magnezyum, diyet lif, pektin, limonoidler ve fenolik bileşikler için iyi birer kaynaktırlar (Baker, 1994; Rouseff ve Nagy, 1994; Farnworth ve ark., 2001; Yllmaz, 2002; Gölükcü ve ark., 2015). Taze olarak tüketilebilmekle beraber ürünlere de işlenebilmekte, yan ürünleri ise önemli ölçüde antioksidan maddeler ve diyet lifler içermektedir (Kang ve ark., 2006).

Turunçgiller diyet lifler açısından oldukça önemli kaynaklar olarak görülmekte, diğer meyvelere benzer şekilde ise kabukları meyve etine göre daha fazla diyet lif içermektedir (Gorinstein ve ark., 2001; Tokgöz ve Gölükcü, 2009). Turunçgil kabukları; karotenoid pigmentleri nedeniyle sarıdan turuncuya kadar değişen ve uçucu yağlar üreten yağ keselerinin bulunduğu flavedo tabakası ile, bu flavedonun hemen altında bulunan beyaz/krem renkteki, besin maddeleri ve suyun taşınmasını sağlayan damarların bulunduğu albedo tabakasından meydana gelir (Turhan ve ark., 2006; Coksever, 2009). Albedo, çoğunlukla pektin ile hesperidinden oluşmakta, turunçgil kabuklarında \%30-35 oranında bulunan pektinin ise \%73'ünü içermektedir (Sinclair, 1984; Schröder ve ark., 2004; Çoksever, 2009). Turunçgillerin albedo tabakası, zengin pektin içeriğinin yanı sıra, bileşiminde bulunan flavonoidler ve $\mathrm{C}$ vitamini gibi antioksidan özellikteki biyoaktif bileşenlerle de ticari üretimde kullanılabilecek yüksek kaliteli bir lif kaynağı olarak görülebilmektedir (Koubala ve ark., 2008; Çoksever, 2009; Demirel ve Demir, 2018).

Besleyici, doyurucu özellikte, nötr bir aromaya sahip ve temini kolay bir ürün olan ekmeğin üretimi kısaca; buğday unu, maya, tuz ve suyun karıştırılmasıyla elde edilen hamurun fermente edildikten sonra pişirilmesi şeklindedir (Elgün ve Ertugay, 1995). Türkiye'de ekmek tüketimi fazla olup, unun değirmende işlenmesi sırasında B grubu vitaminler başta olmak üzere, $\mathrm{Ca}, \mathrm{Fe}, \mathrm{Zn}$ gibi mineral maddeler ve amino asit içerikleri düşmekte, dolayısıyla ekmeğin besin değeri azalmaktadır. Gerek bu olumsuzlukları gidermek gerekse tüketicilerin sağlıklı ürünlere olan talebini karşılamak için zenginleştirme çalışmaları yapılmaktadır (Elgün ve Ertugay, 1995; Kotancılar ve ark., 1995) Ayrıca hazırlanmasındaki kolaylık, maliyetindeki düşüklük, hızlı ve kolay pişirilmeleri nedenleriyle tahıl ürünleri zenginleştirmeye uygun bir gıda grubu olarak görülmekte; vitamince zenginleştirilmiş, yüksek proteinli, düşük şekerli, glutensiz, diyet lifi açısından zengin ekmekler vb. geniş bir ürün yelpazesinde çeşitli fonksiyonel ürünler geliştirilmektedir (Eyidemir, 2006; Yılmaz, 2019). Tüm bu geliştirilen yeni fonksiyonel özellikteki ürünler arasında diyet lifi katkılı ekmekler ayrıca dikkat çekmekte, ekmek üretiminde farklı unların kullanımı ise, birden fazla fonksiyonel etkiye sahip ürünler için yeni bir yaklaşım olarak görülmektedir (Yılmaz, 2019).

$\mathrm{Bu}$ araştırmada; turunçgil sanayinin yan ürünlerinden olan albedoların, temel besin maddelerimizden ekmek üretiminde kullanım imkânlarının araştırılması hedeflenmiştir. Bu amaçla da; buğday unlarına belirli oranlarda ikame edilen farklı turunçgil albedolarının ekmek üretimi için uygunluğunun belirlenmesi ve değerlendirilmesi gerçekleştirilmiştir. 


\section{MATERYAL ve METOD}

\section{Materyal}

Denemelerde kullanılan buğday unu $\quad \begin{array}{ll}\% & 70\end{array}$ randımanlı) Konya ilindeki bir un fabrikasından (Hekimoğlu Un Fabrikası, Konya) temin edilmiştir. Ayrıca ekmek üretiminde kullanılan yaş maya (Saccharomyces cerevisiae), sofra tuzu ve albedo üretiminde kullanılan turunçgiller (portakal, limon ve mandalina) Konya piyasasından temin edilmiştir.

\section{Metot}

\section{Deneme Planı}

Denemede üç farklı turunçgilden (portakal, limon ve mandalina) elde edilen albedolar, ekmek üretiminde buğday ununa 5 farklı ikame oranında $\% 0,2.5,5.0$, 7.5 ve 10), $100 \mathrm{~g}$ un esasına göre ikame edilmiştir. Denemeler (3x5)x2 faktöriyel deneme desenine göre, 2 tekerrürlü olarak yürütülmüştür.

\section{Turunçgil Albedoların Elde Edilmesi}

Denemelerde kullanılan, limon, portakal ve mandalina kabuklarının flavedo ve albedo tabakaları bıçak ile birbirinden ayrılmıştır. Ayrıştırılan albedo tabakaları, kurutma prosesinin kolaylaştırılması için küçük parçalara ayrılarak, $80^{\circ} \mathrm{C}$ 'deki bir kurutma kabininde (Nüve KD-200, Ankara, Türkiye) 18 saat süreyle kurutulmuştur. Albedolar kuruduktan sonra, laboratuvar tipi bir öğütücü (Trisa Coffee Mill, Tokyo, Japonya) ile $500 \mu \mathrm{m}$ elekten geçecek şekilde öğütülmüştür. Daha sonra bu örnekler, 500 ile 180 $\mu$ m'lik eleklerden 5 dakika süre ile elenmiş, iki elek arasında kalan kısım materyal olarak kullanılmıştır.

\section{Ekmek Üretimi}

Ekmek örneklerinin üretim denemelerinde kullanılan direkt pişirme metodu (AACC 10-10), Türk usulü ekmeklere göre modifiye edilmiştir. Bu metotla; $100 \mathrm{~g}$ esasına göre buğday unu, yaklaşık $60 \mathrm{ml} \mathrm{su,} \mathrm{\% 1.0} \mathrm{sofra}$ tuzu ve \%3.0 yaş maya yoğrularak olgun hamur elde edilmiş, daha sonra \% 80-90 nispi nem ve $30^{\circ} \mathrm{C}$ sicaklık koşullarında 2 defa 30'ar dakikalık kitle fermantasyonuna bırakılmış ve fermantasyonların sonunda katlanıp havalandırılmıştır. Ardından hamura son şekli verilmiş, $30^{\circ} C^{\prime}$ de 60 dakika boyunca son fermantasyon gerçekleştirilmiştir. Kabaran hamurlar $230 \pm 5^{\circ}$ C'deki firında (LG MP-9485S, Seul, Kore) 15 dakika pişirilmiştir. Ekmeklerin, bir saat süre ile soğuması beklenmiş, ardından polietilen torbalara konularak ağıları kapatılmıştır (Elgün ve ark., 2005).

\section{Fiziksel ve Kimyasal Analizler}

Ekmek örneklerinin, fırın çıkışında ağırlık ve hacim ölçümleri (kolza tohumuyla yer değiştirme esasına göre) yapılmış, spesifik hacim değerleri hesaplanmıştır (Elgün ve ark., 2005). Örneklerin paralellerinden biri, ağılı elektrikli bıçak ile özel yapılmış kalıp yardımıyla 5 ayrı dilime kesilmiş, orta dilim renk tayininde kullanılmış, iki yan dilimin içe bakan yüzeylerinde ise tekstür analiz cihazı (TA-XT plus, Stable Microsystems, UK) yardımıyla $36 \mathrm{~mm}$ 'lik prob (P/36) ile sertlik değerleri (g) ölçülmüştür (AACC, 1990).

Turunçgil albedoları, buğday unu ve üretimi gerçekleştirilen ekmeklerin renk okumaları, Hunter Lab Color Quest II Minolta CR-400 (Konica Minolta Sensing, Inc., Osaka, Japan) cihazı kullanılarak $L^{*}$ değeri [ (0) siyah- (100) beyaz ], $a^{*}$ değeri [ (+) kırmızi(-) yeşil ] ve $b^{*}$ değeri [ (+) sarı- (-) mavi ] cinsinden ölçülmüştür (Francis, 1998).

Denemelerde kullanılan buğday unu, turunçgil albedoları ve ekmek örneklerinin nem miktarı, $135^{\circ} \mathrm{C}$ 'de 2.5 saat kurutma normu uygulanarak hesaplanmıştır (metot no: 44-19). Örneklerin protein tayinleri Kjeldahl metoduyla yapılmış (metot no: 4612 ), buğday unu sonuçları 5.70, albedolarınki ise 6.25 çarpım faktörü ile hesaplanarak kuru madde esasına göre verilmiştir (AACC 1990). Kül tayini AACC 08-01 metodu kullanılarak, ham lif miktarı ise AACC 32-10 metoduna göre yapılmıştır (AACC, 1990). Fitik asit değerleri, kolorimetrik metot kullanılarak, Haug ve Lantzsch (1983)'e göre belirlenmiştir. Örnekteki fitik asit, hidroklorik asit çözeltisi ile ekstrakte edilmiş ve Demir III çözeltisi ile çöktürülerek serum kısmında kalan demir miktarı spektrofotometrik (Libra S60, Biochrom Ltd., Cambridge, England) yolla belirlenmiş, buradan da fitik asit miktarı hesaplanmıştır. Sonuçlar mg 100 g-1 cinsinden verilmiştir.

\section{Duyusal analizler}

Ekmek örneklerinin duyusal analizi; Necmettin Erbakan Üniversitesi Mühendislik ve Mimarlık Fakültesi Gıda Mühendisliği bölümündeki öğretim elemanları, lisans ve lisansüstü öğrencilerinden oluşturulan, yaşları 18-40 arasında değişen ve konu ile ilgili aynı koşullar altında kısa bir eğitime tabi tutulan, 10 kişilik panelist grubu tarafından gerçekleştirilmiştir. Duyusal değerlendirmede ise; tadım için küçük kare dilimler halinde sunulan ekmek örnekleri ile görsel değerlendirmeler için pişirilmiş ekmek örnekleri panelistlere ayrı ayrı sunulmuş olup; tat-koku, renk, tekstür, gözenek yapısı ve genel beğeni açısından; 1-5 arasındaki skala (1-kötü, 3-kabul edilebilir ve 5-oldukça iyi) kullanılarak değerlendirme yapmaları istenmiştir ve sonuçta elde edilen verilerin tümü ortak değerlendirmeye tabi tutulmuştur.

\section{İstatistiki Analizler}

Denemeler 2 tekerrürlü olarak yürütülmüş olup, araştırma sonucunda elde edilen veriler varyans analizine tabi tutulmuş; farklılıkları istatistiki olarak önemli bulunan ana varyasyon kaynaklarının ortalamaları ise Duncan çoklu karşılaştırma testi ile 
karşılaştırılmıştır. İstatistiki analiz sonuçları tablolar halinde özetlenmiştir (Düzgüneş ve ark., 1987).

\section{BULGULAR ve TARTIŞMA}

Analitik Sonuçlar

Denemelerde kullanılan hammaddelere ait analitik analiz sonuçları Çizelge 1'de verilmiştir.

Buğday unu ve turunçgil albedoları karşılıklı incelendiğinde, ham lif ve kül miktarları bakımından, albedoların daha yüksek içeriklere sahip olduğu görülmüştür. Protein oranlarının ise, albedolarda daha düşük olduğu belirlenmiştir. Dolayısıyla, albedoların ikame edildiği miktara bağlı olarak ekmeklerin kül ve ham lif miktarını arttırması, protein oranını az da olsa düşürmesi beklenmektedir. Renk değerleri incelendiğinde turunçgil albedolarının $L^{*}$ değeri, ekmeklik una göre düşük bulunmuştur. $a^{*}$ değeri incelendiğinde ise; tüm albedoların ekmeklik una göre daha yüksek kırmızılık değerleri verdiği belirlenmiştir.

Çizelge 1. Buğday unu ve turunçgil albedo örneklerine ait analitik analiz sonuçları ${ }^{1}$

Table 1. Analytical analysis results of bread flour and citrus albedo samples ${ }^{1}$

\begin{tabular}{|c|c|c|c|c|}
\hline Bileşen (Component) & $\begin{array}{l}\text { Un } \\
\text { (Flour) }\end{array}$ & $\begin{array}{l}\text { Portakal } \\
\text { (Orange) }\end{array}$ & $\begin{array}{l}\text { Mandalina } \\
\text { (Mandarin) }\end{array}$ & $\begin{array}{l}\text { Limon } \\
\text { (Lemon) }\end{array}$ \\
\hline$L^{*}$ & $95.17 \pm 0.22$ & $81.56 \pm 0.15$ & $85.28 \pm 0.23$ & $90.28 \pm 0.22$ \\
\hline$a^{*}$ & $-0.30 \pm 0.09$ & $0.18 \pm 0.08$ & $0.28 \pm 0.12$ & $0.23 \pm 0.13$ \\
\hline$b^{*}$ & $9.29 \pm 021$ & $28.16 \pm 0.40$ & $23.69 \pm 0.30$ & $21.07 \pm 0.42$ \\
\hline Nem (Moisture) (\%) & $10.59 \pm 0.15$ & $8.23 \pm 0.15$ & $8.42 \pm 0.03$ & $8.21 \pm 0.06$ \\
\hline Ham Kül (Crude Ash) (\%)2 & $0.59 \pm 0.01$ & $2.73 \pm 0.04$ & $2.88 \pm 0.04$ & $3.06 \pm 0.07$ \\
\hline Ham Protein (Crude Protein) (\%)2,3 & $11.62 \pm 0.19$ & $3.81 \pm 0.07$ & $3.62 \pm 0.08$ & $3.68 \pm 0.24$ \\
\hline Ham Lif (Crude Fiber) (\%)2 & $0.25 \pm 0.01$ & $18.78 \pm 0.47$ & $18.71 \pm 0.44$ & $18.93 \pm 0.38$ \\
\hline
\end{tabular}

${ }^{1}$ Sonuçlar iki tekerrürün ortalamasıdır ve; ${ }^{2}$ Sonuçlar kuru madde üzerinden verilmiştir; ${ }^{3}$ Buğday unu: $\mathrm{N}$ x 5.70, Albedo: $\mathrm{N}$ x 6.25 çarpım faktörleriyle hesaplanmıştır.

${ }^{1}$ Results are the average of two repeats; ${ }^{2}$ Results are given on dry matter; The factor for Wheat flour: $\mathrm{N}$ x 5.70 , for Albedos: $\mathrm{N}$ x 6.25 .

Ayrıca turunçgil albedoları $b^{*}$ değerlerinin, ekmeklik undan daha yüksek olduğu belirlenmiştir. Genel olarak da, ekmeklik buğday ununa göre, albedoların daha koyu-sarı renkli hammaddeler olduğu tespit edilmiştir (Çizelge 1).

\section{Ekmeklerin Renk Özellikleri}

Ekmek örneklerinde $L^{*}$ değerinin yüksek olması, ekmek içi renginin açık olduğunu belirtir (Elgün ve ark., 2002).

Ekmek kabuk rengi oluşumunda en önemli faktörler karamelizasyon ve Maillard reaksiyonlarıdır. Bu reaksiyonlar ekmek yüzeyinde kırmızı-esmer parlak renge, dekstrinler ise parlak yüzey oluşumuna neden olurlar (Demir ve ark., 2006). Dolayısıyla ekmek rengi, son ürün kalitesi açısından önemli bir parametredir. Üretilen ekmek örneklerinin kabuk ve iç renk $L^{*}, a^{*}$ ve $b^{*}$ değerlerine ait Duncan çoklu karşlaştırma testi sonuçları Çizelge 2'de özetlenmiştir.

Çizelge 2. Ekmeklerin renk özellikleri üzerine turunçgil albedolarının etkisi ${ }^{1}$

Table 2. Effect of citrus albedos on the color properties of bread ${ }^{1}$

\begin{tabular}{llcccccc}
\hline \multirow{2}{*}{ Faktör (Factor) } & \multicolumn{2}{c}{ Kabuk Rengi (Crust Color) } & \multicolumn{3}{c}{ İç Renk (Crumb Color) } \\
\cline { 2 - 7 } & \multicolumn{2}{c}{$L^{*}$} & $a^{*}$ & $b^{*}$ & $L^{*}$ & $a^{*}$ & $b^{*}$ \\
Turunçgil & $\begin{array}{l}\text { Portakal } \\
\text { (Orange) }\end{array}$ & $56.20 \pm 0.05^{\mathrm{a}}$ & $9.53 \pm 0.10^{\mathrm{a}}$ & $19.66 \pm 0.08^{\mathrm{a}}$ & $70.14 \pm 0.06^{\mathrm{b}}$ & $0.30 \pm 0.02^{\mathrm{a}}$ & $6.37 \pm 0.08^{\mathrm{a}}$ \\
Çeșidi & $\begin{array}{l}\text { Limon } \\
\text { (Lemon) }\end{array}$ & $56.15 \pm 0.09^{\mathrm{a}}$ & $9.08 \pm 0.13^{\mathrm{b}}$ & $19.47 \pm 0.08^{\mathrm{b}}$ & $70.41 \pm 0.08^{\mathrm{a}}$ & $0.27 \pm 0.02^{\mathrm{a}}$ & $6.45 \pm 0.07^{\mathrm{a}}$ \\
Type) & $\begin{array}{l}\text { Mandalina } \\
\text { (Mandarin) }\end{array}$ & $55.95 \pm 0.05^{\mathrm{b}}$ & $9.02 \pm 0.12^{\mathrm{b}}$ & $19.48 \pm 0.05^{\mathrm{b}}$ & $70.19 \pm 0.10^{\mathrm{b}}$ & $0.24 \pm 0.02^{\mathrm{b}}$ & $6.44 \pm 0.09^{\mathrm{a}}$ \\
\hline Oran & 0 & $59.39 \pm 0.04^{\mathrm{a}}$ & $6.48 \pm 0.02^{\mathrm{e}}$ & $18.45 \pm 0.06^{\mathrm{e}}$ & $72.40 \pm 0.06^{\mathrm{a}}$ & $-0.35 \pm 0.02^{\mathrm{e}}$ & $5.24 \pm 0.18^{\mathrm{e}}$ \\
(\%) & 2.5 & $57.38 \pm 0.07^{\mathrm{b}}$ & $7.85 \pm 0.10^{\mathrm{d}}$ & $18.75 \pm 0.08^{\mathrm{d}}$ & $71.40 \pm 0.08^{\mathrm{b}}$ & $0.14 \pm 0.02^{\mathrm{d}}$ & $5.86 \pm 0.09^{\mathrm{d}}$ \\
(Ratio) & 5.0 & $56.15 \pm 0.07^{\mathrm{c}}$ & $9.06 \pm 0.12^{\mathrm{c}}$ & $19.29 \pm 0.08^{\mathrm{c}}$ & $70.16 \pm 0.08^{\mathrm{c}}$ & $0.28 \pm 0.02^{\mathrm{c}}$ & $6.41 \pm 0.07^{\mathrm{c}}$ \\
(\%) & 7.5 & $54.88 \pm 0.06^{\mathrm{d}}$ & $10.60 \pm 0.11^{\mathrm{b}}$ & $20.12 \pm 0.12^{\mathrm{b}}$ & $69.51 \pm 0.09^{\mathrm{d}}$ & $0.55 \pm 0.03^{\mathrm{b}}$ & $7.07 \pm 0.04^{\mathrm{b}}$ \\
\hline
\end{tabular}

${ }^{1}$ Aynı harfle işaretlenmiş ortalamalar istatistiki olarak birbirinden farklı değildir ( $\left.\mathrm{P}>0.05\right)$.

${ }^{1}$ Averages marked with the same letter are not statistically different from each other $(\mathrm{P}>0.05)$.

Portakal albedosu ikameli ekmeklerin kabuklarının $a^{*}$ ve $b^{*}$ değerleri, diğer albedo ikamelerine göre yüksek bulunmuş ve sonuçlar arasında da istatistiki olarak önemli farklılıklar tespit edilmiştir $\quad(\mathrm{P}<0.05)$. Turunçgil albedo ikamesi ile örneklerin hem kabuklarının hem de iç dokularının $L^{*}$ (parlaklık) 
değerlerinde istatistiki olarak önemli azalmalar meydana gelmiştir. En yüksek parlaklık değerleri kontrol grubunda (\%0 albedo ikameli ekmek) elde edilmiştir. En düşük parlaklık değerleri ise \%10 turunçgil albedosu ikameli ekmeklerde tespit edilmiştir. Ekmek üretiminde kullanılan hammaddelerin renk değerlerini gösteren Çizelge 1 incelendiğinde, buğday ununun $L^{*}$ değerinin, turunçgil albedo örneklerinden daha yüksek olduğu görülmektedir. Bu sebeple örneklerde azalan buğday unu oranının, $L^{*}$ değerinde de azalmaya sebep olduğu düşünülmektedir.

Ayrıca, ekmek bileşimine dahil edilen turunçgil albedoları ile örneklerin kabuk ve iç dokularında $a^{*}$ (kırmızllık) ve $b^{*}$ (sarılık) değerinin istatistik olarak $(\mathrm{P}<0.05)$ arttığ tespit edilmiştir. Genel olarak da, turunçgil albedosu ikamesi ve ikame oranlarında artışa gidilmesi, son ürünlerin renginde değişimlere sebep olmuş, daha kırmızı ve koyu renkli ürünlerin eldesini mümkün kılmıştır. Ekmek örneklerinin hem iç dokularında hem de kabuklarındaki $a^{*}$ ve $b^{*}$ değerlerindeki artışın muhtemel sebebi, hammadde olarak kullanılan albedoların $a^{*}$ ve $b^{*}$ değerlerinin buğday unundan yüksek olmasıdır. Ocen ve Xu (2013) portakal lifi ikameli ekmek üzerine yaptıkları çalışmalarında portakal atıklarından elde edilen lifin ikame oranının artmasiyla ekmek örneklerinde $L^{*}$ değerlerinin azaldığını, $a^{*}$ ve $b^{*}$ değerlerinin ise arttığını bildirmişlerdir. Ayrıca ekmeklerin kabuklarında artan sarılık ve kırmızılık değerlerinde, Maillard reaksiyonunun da etkili olabileceği düşünülmektedir (Demir ve ark., 2006).

\section{Ekmeklerin Ağırlık, Hacim, Spesifik Hacim ve Sertlik Özellikleri}

Üretilen ekmek örneklerinin ağırlık, hacim, spesifik hacim ve sertlik değerlerine ait Duncan çoklu karşılaştırma testi sonuçları Çizelge 3'te özetlenmiştir. Çizelge 3'e göre; turunçgil çeşitleri ekmek örneklerinin ağırlık, hacim, spesifik hacim ve sertlik değerleri üzerinde istatistiki olarak önemli etkisi bulunmamıştır $(\mathrm{P}>0.05)$.

Çizelge 3. Ekmeklerin fiziksel özellikleri üzerine turunçgil albedoların etkisi ${ }^{1}$

Table 3. Effect of citrus albedos on the physical properties of bread ${ }^{1}$

\begin{tabular}{|c|c|c|c|c|c|}
\hline \multicolumn{2}{|c|}{ Faktör (Factor) } & $\begin{array}{c}\text { Ağırlık } \\
(\text { Weight })(\mathrm{g})\end{array}$ & $\begin{array}{c}\text { Hacim } \\
\text { (Volume) (cc) }\end{array}$ & $\begin{array}{c}\text { Spesifik Hacim } \\
\text { (Specific Volume) }(\mathrm{cc} \mathrm{g-1)}\end{array}$ & $\begin{array}{c}\text { Sertlik } \\
(\text { Firmness) (g) }\end{array}$ \\
\hline \multirow{3}{*}{$\begin{array}{l}\text { Turunçgil } \\
\text { Çeşidi } \\
\text { (Citrus } \\
\text { Type) }\end{array}$} & $\begin{array}{l}\text { Portakal } \\
\text { (Orange) }\end{array}$ & $151.78 \pm 0.19^{\mathrm{a}}$ & $359.5 \pm 6.36^{\mathrm{a}}$ & $2.37 \pm 0.04^{\mathrm{a}}$ & $1004 \pm 19.37^{\mathrm{a}}$ \\
\hline & $\begin{array}{l}\text { Limon } \\
\text { (Lemon) }\end{array}$ & $151.74 \pm 0.10^{\mathrm{a}}$ & $361.5 \pm 4.95^{\mathrm{a}}$ & $2.39 \pm 0.03^{\mathrm{a}}$ & $1021 \pm 21.92^{\mathrm{a}}$ \\
\hline & $\begin{array}{l}\text { Mandalina } \\
\text { (Mandarin) }\end{array}$ & $151.92 \pm 0.18^{\mathrm{a}}$ & $366.5 \pm 4.95^{\mathrm{a}}$ & $2.42 \pm 0.03^{\mathrm{a}}$ & $996 \pm 18.37^{\mathrm{a}}$ \\
\hline \multirow{5}{*}{$\begin{array}{l}\text { Oran } \\
(\%) \\
\text { (Ratio) } \\
(\%)\end{array}$} & 0 & $149.78 \pm 0.30^{\mathrm{e}}$ & $435.0 \pm 7.07^{\mathrm{a}}$ & $2.91 \pm 0.04^{\mathrm{a}}$ & $698 \pm 16.97$ e \\
\hline & 2.5 & $150.38 \pm 0.10^{\mathrm{d}}$ & $401.7 \pm 4.71^{\mathrm{b}}$ & $2.67 \pm 0.03^{b}$ & $818 \pm 24.28^{\mathrm{d}}$ \\
\hline & 5.0 & $151.45 \pm 0.04^{\mathrm{c}}$ & $363.3 \pm 4.71^{\mathrm{c}}$ & $2.40 \pm 0.03^{\mathrm{c}}$ & $953 \pm 15.08^{c}$ \\
\hline & 7.5 & $153.06 \pm 0.15^{b}$ & $317.5 \pm 5.89^{\mathrm{d}}$ & $2.08 \pm 0.04^{\mathrm{d}}$ & $1127 \pm 27.58^{b}$ \\
\hline & 10.0 & $154.39 \pm 0.21^{\mathrm{a}}$ & $295.0 \pm 4.71 \mathrm{e}$ & $1.91 \pm 0.03^{\mathrm{e}}$ & $1439 \pm 15.56^{\mathrm{a}}$ \\
\hline
\end{tabular}

${ }_{1}^{1}$ Aynı harfle işaretlenmiş ortalamalar istatistiki olarak birbirinden farklı değildir $(\mathrm{P}>0.05)$.

${ }^{1}$ Averages marked with the same letter are not statistically different from each other $(\mathrm{P}>0.05)$.

Albedo oranının etkisi incelendiğinde ise, en düşük ekmek ağırlığı değerleri albedo katkısız kontrol grubu ekmeklerde tespit edilmiş olup, albedo oranında artışa gidilmesinin ekmek ağırlık değerlerini arttırıcı etkide bulunduğu belirlenmiştir (Çizelge 3). Ekmek hacim değerleri ile spesifik hacim değerleri ise artan albedo ikame oranına bağlı olarak istatistiki olarak azalma göstermiştir. Ekmek hacim değerleri ile ekmek spesifik hacim değerleri arasındaki paralellikten dolayı böyle bir artışın olması doğaldır (Elgün ve Ertugay, 1995). Ayrica ekmek spesifik hacim değerlerinin düşmesi ile daha sert ekmeklerin eldesi sağlamıştır. Bir başka deyişle albedo ikamesi oranlarındaki artışlar ekmeklerin sertlik değerlerini istatistiki olarak $(\mathrm{P}<0.05)$ arttırmıştır. Miller (2011) narenciyelerin kabuk lifi, Ocen ve $\mathrm{Xu}$ (2013) ise portakal lifi katkısıla ekmek örneklerinin hacim değerlerinin düştüğünü, sertlik değerlerinin ise arttığını bildirmişlerdir. Artan albedo ikame oranıyla örneklerin ağırlığının ve sertliğinin artması, hacim değerlerinin ise azalması, ekmeklerde lif içeriğinin dolayısıyla su absorbsiyon kapasitesinin artmasina atfedilebilir (Bozdoğan, 2015; Qureshi ve ark., 2017).

\section{Ekmeklerin Kimyasal Özellikleri}

Farklı çeşit ve oranlarda turunçgil albedosu ikame edilen ekmek örneklerinin bazı kimyasal özelliklerine ait Duncan çoklu karşılaş̧ırma testi sonuçları Çizelge 4 'te verilmiştir.

Farklı çeşit turunçgil albedosu (portakal, limon ve mandalina) ikame edilerek üretilen ekmeklerin, ham kül, protein, lif ve fitik asit değerlerinin istatistiki olarak değişmediği $(\mathrm{P}>0.05)$ tespit edilmiştir. 
Çizelge 4. Ekmeklerin kimyasal özellikleri üzerine turunçgil albedoların etkisi ${ }^{1}$

Table 4. Effect of citrus albedos on the chemical properties of bread ${ }^{1}$

\begin{tabular}{|c|c|c|c|c|c|}
\hline \multicolumn{2}{|c|}{ Faktör (Factor) } & $\begin{array}{l}\text { Ham Kül } \\
\text { (Crude Ash) } \\
(\%)\end{array}$ & $\begin{array}{c}\text { Ham Protein } \\
\text { (Crude Protein) } \\
(\%)\end{array}$ & $\begin{array}{c}\text { Ham Lif } \\
\text { (Crude Fiber) } \\
(\%)\end{array}$ & $\begin{array}{l}\text { Fitik Asit } \\
\text { (Phytic Acid) } \\
\text { (mg } 100 \mathrm{~g}-1)\end{array}$ \\
\hline \multirow{3}{*}{$\begin{array}{l}\text { Turunçgil } \\
\text { Çeşidi } \\
\text { (Citrus Type) }\end{array}$} & $\begin{array}{l}\text { Portakal } \\
\text { (Orange) }\end{array}$ & $1.15 \pm 0.01^{\mathrm{a}}$ & $11.59 \pm 0.04^{\mathrm{a}}$ & $1.10 \pm 0.02^{\mathrm{a}}$ & $87.11 \pm 0.39^{\mathrm{a}}$ \\
\hline & Limon & $1.16 \pm 0.01^{\mathrm{a}}$ & $11.58 \pm 0.03^{\mathrm{a}}$ & $1.12 \pm 0.01^{\mathrm{a}}$ & $86.85 \pm 0.29^{a}$ \\
\hline & $\begin{array}{l}\text { Mandalina } \\
\text { (Mandarin) }\end{array}$ & $1.17 \pm 0.01^{\mathrm{a}}$ & $11.61 \pm 0.03^{\mathrm{a}}$ & $1.11 \pm 0.02^{\mathrm{a}}$ & $86.91 \pm 0.35^{\mathrm{a}}$ \\
\hline \multirow{5}{*}{$\begin{array}{l}\text { Oran } \\
\text { (\%) } \\
\text { (Ratio) } \\
(\%)\end{array}$} & 0 & $1.02 \pm 0.02^{\mathrm{e}}$ & $12.07 \pm 0.08^{\mathrm{a}}$ & $0.20 \pm 0.01^{\mathrm{e}}$ & $89.94 \pm 0.12^{\mathrm{a}}$ \\
\hline & 2.5 & $1.11 \pm 0.01^{\mathrm{d}}$ & $11.81 \pm 0.04^{\mathrm{b}}$ & $0.62 \pm 0.02^{\mathrm{d}}$ & $88.72 \pm 0.33^{\mathrm{b}}$ \\
\hline & 5.0 & $1.16 \pm 0.01^{\mathrm{c}}$ & $11.56 \pm 0.02^{\mathrm{c}}$ & $1.14 \pm 0.05^{\mathrm{c}}$ & $86.83 \pm 0.86^{c}$ \\
\hline & 7.5 & $1.22 \pm 0.01^{b}$ & $11.36 \pm 0.03^{\mathrm{d}}$ & $1.58 \pm 0.04^{b}$ & $85.16 \pm 0.15^{\mathrm{d}}$ \\
\hline & 10.0 & $1.29 \pm 0.02^{\mathrm{a}}$ & $11.15 \pm 0.03^{\mathrm{e}}$ & $2.02 \pm 0.02^{\mathrm{a}}$ & $84.14 \pm 0.28^{e}$ \\
\hline
\end{tabular}

${ }^{1}$ Aynı harfle işaretlenmiş ortalamalar istatistiki olarak birbirinden farklı değildir $(\mathrm{P}>0.05)$.

${ }^{1}$ Averages marked with the same letter are not statistically different from each other $(\mathrm{P}>0.05)$.

Buna karşın; ekmeklerde albedo ikame oranı arttıkça, ham kül ve ham lif miktarlarının arttığı, ham protein ve fitik asit miktarının ise azaldığ $(\mathrm{P}<0.05)$ tespit edilmiştir. Bu sonuçların muhtemel sebebi; ekmeklik unların protein ve fitik asit miktarının turunçgil albedolarına kıyasla daha yüksek olmasıdır (Çizelge 1). Bu durum, albedo ikamesiyle ekmek örneklerinin ham protein ve fitik asit miktarının düşmesine sebep olmaktadır. Ayrıca; fitik asitin, bütün bitkisel hücrelerde bulunan bir bileşik olmasına karşın, tahıl ve baklagillerde daha fazla bulunduğu bilgisinden yola çıkarak, ekmek örneklerinde fitik asit içeriklerinin düşmesinin, buğday ununun albedolarla yer değiştirmesinden kaynaklandığı söylenebilmektedir (Şat ve Keleş, 2014). Turunçgil albedoları buğday ununa kıyasla daha yüksek organik ve inorganik maddeler içerdiği, özellikle de selüloz, diyet lif ve pektin içeriği ile dikkat çeken yan ürünler olduğu için, Çizelge 4'te görüldüğü üzere ekmeklere ikame edildiğinde örneklerin bazı kimyasal özelliklerini geliştirmiştir (Bilgiçli ve ark., 2014). Dolayısıyla, ekmeklerin kimyasal analiz özelliklerindeki artış ve azalışların hammadde kaynaklı olduğu belirlenmiştir. Yani üretimde kullanılan hammaddeler son ürünün kimyasal bileşenlerine doğrudan etki etmiştir. Dolayısıyla ikame oranında artışa gidilmesi son ürünlerde, protein içerikleri hariç, besinsel özelliklerin gelişmesi açısından önemli katkılar sağlamıştır. Bozdoğan (2015) ile Qureshi ve ark. (2017) kek örnekleri üzerine, Uchoa ve ark. (2009) ile Aydın (2014) ise bisküvi örnekleri üzerine yaptıkları çalışmalarında, örneklerdeki diyet lif miktarının artmasının su tutma kapasitesini artırdığını, dolayısıyla örneklerin nem içeriğinde de bir artış meydana geldiğini bildirmişlerdir. Literatürde, greyfurt albedosu tozu ikamesiyle kek örneklerinin protein içeriklerinin \%13.19'dan \%12.57'ye düştüğü bilgisi de yer almaktadır (Qureshi ve ark., 2017).

\section{Ekmeklerin Duyusal Analiz Özellikleri}

Ekmek örneklerinin 1-5 puan skalası ile değerlendirmeye tabi tutulan bazı duyusal özelliklerine ait veriler Çizelge 5'te özetlenmiştir. Çizelge 5'e göre, turunçgil çeşitleri arasında herhangi bir farklılık tespit edilmemiştir. Genel olarak albedo ikamesinin artmasına bağlı olarak duyusal beğeninin azaldığı tespit edilmiştir. Albedo ikamesi yapılmayan kontrol grubu ekmeklere en yakın duyusal değerlendirme puanları \%2.5 oranında albedo ikamesine sahip ekmeklerde elde edilmiştir. Albedo ikame oranının artması ile tüm puanlama değerleri bariz bir şekilde azalmıştır. En az duyusal beğeni skorlarını ise \%10.0 albedo ikameli ekmekler vermiştir. $\mathrm{Bu}$ durum, turunçgil albedoları elde edilirken flavedo tabakasından geçen acılık veren maddelerden ve albedoların yüksek lif içeriğinden, pişirme prosesindeki renk koyulaşmalarından ileri gelmektedir (Demirel, 2017). Can (2015) bisküviye portakal kabuğu tozunu ikame ettiği çalışmasında, ikame oranının artmasına bağlı olarak duyusal puanların giderek azaldığını bildirmiştir. Uysal (2005) farklı lif kaynaklarını bisküvi bileşimine eklediği bir çalışmasında, tüm lif kaynağı çeşitlerinde oranın artmasına bağlı olarak duyusal değerlerde verdiği puanların düştüğünü belirtmiştir.

\section{SONUÇ ve ÖNERİLER}

Bu çalışmada, buğday unu yerine farklı oranlarda (\%0, $\% 2.5, \% 5, \% 7.5$ ve \%10) turunçgil albedoları (portakal, limon ve mandalina) formülasyona dahil edilerek ekmek üretiminde kullanılma imkanları incelenmiş, üretilen bu ekmeklerde bazı fiziksel, kimyasal ve duyusal özelliklerin değişimleri araştırılmış ve aşağıdaki sonuçlar elde edilmiştir.

1) Ekmek örneklerinin renk değerleri incelendiğinde; portakal, limon ve mandalina albedosu ikamesinin artmasına bağlı olarak, tüm örneklerin kabuk ve iç 
dokularında $L^{*}$ değerlerinin azaldığı, $a^{*}$ ve $b^{*}$ değerlerinin ise arttığ gözlenmiştir.

2) Albedo oranlarında artışa gidilmesi ile ekmeklerin ağırlıkları ve sertliklerinin arttığı, hacim ve spesifik hacim değerlerinin azaldığı tespit edilmiştir. Farkl turunçgil çeşitlerinin kullanılması ise bu özellikler (ekmek ağırlığı, hacimi, spesifik hacmi ve sertliği) üzerinde önemli bir değişikliğe sebep olmamıştır.

3) Üretilen ekmek örnekleri kimyasal özellikler bakımından incelendiğinde; albedo ikamesinin artmasına bağlı olarak, tüm örneklerde ham kül ve ham lif miktarlarının arttığı, fitik asit değerlerinin ise azaldığ 1 tespit edilmiştir.

4) Duyusal analiz sonuçlarına göre; ekmek üretiminde \%2.5'e kadar albedo ikamesinde örneklerin kontrole eşdeğer özelliklere sahip olduğu, \%2.5 üzerindeki kullanımda ekmeklerin duyusal özelliklerinin olumsuz etkilendiği belirlenmiştir.

Çizelge 5. Ekmeklerin duyusal özellikleri üzerine turunçgil albedoların etkisi (1-5 puan)

Table 5. Effect of citrus albedos on the sensory properties of bread (1-5 points)

\begin{tabular}{|c|c|c|c|c|c|c|}
\hline $\begin{array}{l}\text { Turunçgil Çeşidi } \\
\text { (Citrus Type) }\end{array}$ & $\begin{array}{l}\text { Oran } \\
\text { (Ratio) (\%) }\end{array}$ & $\begin{array}{l}\text { Tat-Koku } \\
\text { (Taste-Odor) }\end{array}$ & Renk (Color) & $\begin{array}{l}\text { Tekstür } \\
\text { (Texture) }\end{array}$ & $\begin{array}{c}\text { Gözenek } \\
\text { Yapısı } \\
\text { (Pore } \\
\text { Structure) }\end{array}$ & $\begin{array}{l}\text { Genel } \\
\text { Beğeni } \\
\text { (General } \\
\text { Acclaim) }\end{array}$ \\
\hline \multirow{5}{*}{$\begin{array}{l}\text { Portakal } \\
\text { (Orange) }\end{array}$} & 0 & $4.2 \pm 0.05$ & $4.5 \pm 0.04$ & $4.5 \pm 0.09$ & $4.5 \pm 0.30$ & $4.6 \pm 0.22$ \\
\hline & 2.5 & $4.0 \pm 0.11$ & $4.5 \pm 0.04$ & $4.2 \pm 0.11$ & $4.5 \pm 0.21$ & $4.4 \pm 0.35$ \\
\hline & 5.0 & $4.0 \pm 0.02$ & $4.3 \pm 0.05$ & $4.0 \pm 0.16$ & $4.2 \pm 0.18$ & $4.4 \pm 0.10$ \\
\hline & 7.5 & $3.8 \pm 0.04$ & $4.0 \pm 0.07$ & $3.5 \pm 0.21$ & $4.0 \pm 0.11$ & $4.0 \pm 0.13$ \\
\hline & 10.0 & $3.0 \pm 0.03$ & $3.6 \pm 0.07$ & $3.0 \pm 0.18$ & $3.4 \pm 0.14$ & $3.7 \pm 0.10$ \\
\hline \multirow{5}{*}{$\begin{array}{l}\text { Limon } \\
\text { (Lemon) }\end{array}$} & 0 & $4.2 \pm 0.09$ & $4.5 \pm 0.04$ & $4.5 \pm 0.19$ & $4.5 \pm 0.13$ & $4.5 \pm 0.21$ \\
\hline & 2.5 & $4.0 \pm 0.14$ & $4.5 \pm 0.09$ & $4.3 \pm 0.17$ & $4.5 \pm 0.22$ & $4.4 \pm 0.14$ \\
\hline & 5.0 & $3.5 \pm 0.05$ & $4.5 \pm 0.01$ & $4.1 \pm 0.12$ & $4.0 \pm 0.30$ & $4.2 \pm 0.12$ \\
\hline & 7.5 & $3.0 \pm 0.08$ & $4.2 \pm 0.06$ & $3.4 \pm 0.10$ & $3.8 \pm 0.15$ & $3.7 \pm 0.11$ \\
\hline & 10.0 & $2.0 \pm 0.17$ & $4.0 \pm 0.10$ & $3.1 \pm 0.05$ & $3.5 \pm 0.15$ & $3.5 \pm 0.04$ \\
\hline \multirow{5}{*}{$\begin{array}{l}\text { Mandalina } \\
\text { (Mandarin) }\end{array}$} & 0 & $4.2 \pm 0.15$ & $4.5 \pm 0.12$ & $4.5 \pm 0.14$ & $4.5 \pm 0.15$ & $4.5 \pm 0.12$ \\
\hline & 2.5 & $4.3 \pm 0.04$ & $4.5 \pm 0.14$ & $4.2 \pm 0.04$ & $4.5 \pm 0.25$ & $4.5 \pm 0.18$ \\
\hline & 5.0 & $4.1 \pm 0.04$ & $4.3 \pm 0.04$ & $4.1 \pm 0.06$ & $4.0 \pm 0.16$ & $4.1 \pm 0.10$ \\
\hline & 7.5 & $3.8 \pm 0.10$ & $4.1 \pm 0.01$ & $3.6 \pm 0.15$ & $3.8 \pm 0.15$ & $3.9 \pm 0.08$ \\
\hline & 10.0 & $3.2 \pm 0.17$ & $3.7 \pm 0.06$ & $3.1 \pm 0.17$ & $3.4 \pm 0.12$ & $3.5 \pm 0.15$ \\
\hline
\end{tabular}

Sonuç olarak; ekmek bileşimine farklı oranlarda ikame edilen portakal, limon ve mandalina albedoları, ekmeklerin duyusal özelliklerini düşürmüş, fakat ekmeklerin besleyici özelliklerini artırmıştır. Bunun yanında turunçgil albedoları; besinsel lif içeriğince zengin olmaları, mineral madde miktarlarının yüksek olması ve antibesinsel özellikteki fitik asit miktarlarının düşük olması nedeniyle ekmek bileşimine dahil edilebilir nitelikte bileşenler olarak bulunmuştur.

\section{TEŞEKKÜR}

$\mathrm{Bu}$ araştırma, Necmettin Erbakan Üniversitesi BAP Koordinatörlüğü tarafindan 181219007 proje numarası ile desteklenmiştir.

\section{Çıkar Çatışması Beyanı}

Makale yazarları aralarında herhangi bir çıkar çatışması olmadığını beyan ederler.

\section{KAYNAKLAR}

AACC 1990. American Association of Cereal Chemists, Approved Methods of the AACC. 8th Edition, Saint Paul, Minnesota, USA.
Aktaş K 2012. Sütçülük Yan Ürünleri ve B Glukan İlavesi ile Eriştenin Besinsel Özeliklerinin Artırılması Üzerine Bir Araştırma. Selçuk Üniversitesi Fen Bilimleri Enstitüsü Gıda Mühendisliği Ana Bilim Dalı, Yüksek Lisans Tezi. 110 sy.

Aydın E 2014. Balkabağı (Cucurbita moschata) Unu Katkısının Bisküvinin Antioksidan Aktivite ve Besinsel Kalitesine Etkileri. Uludağ Üniversitesi Fen Bilimleri Enstitüsü Gıda Mühendisliği Ana Bilim Dalı, Doktora Tezi, 151 sy.

Baker R A 1994. Potential Dietary Benefits of Citrus Pectin and Fiber. Food Technology 48:133-137.

Bilgiçli N, Aktaş K, Levent H 2014. Utilization of Citrus Albedo in Tarhana production. Journal of Food nd Nutrition Research 53(2):162-170.

Boyacıoğlu D 2012. Fonksiyonel Gidalar. https://www. foodelphi.com/fonksiyonel-gidalar-roportaj-prof- $\mathrm{dr}^{-}$ dilek-boyacioglu/.

Bozdoğan N 2015. Glutensiz Kek Formülasyonlarında Hidrokolloid ve Diyet Lifi Kullanımının Hamur Reolojisi ve Kek Kalitesi Üzerine Olan Etkilerinin İncelenmesi. Ege Üniversitesi Fen Bilimleri Enstitüsü Gıda Mühendisliği Ana Bilim Dalı, 
Yüksek Lisans Tezi, 146 sy.

Can F 2015. Portakal Kabuğu Tozunun Bisküvi Hamuru ve Bisküvi Kalitesi Üzerine Etkilerinin İncelenmesi. İnönü Üniversitesi Fen Bilimleri Enstitüsü Gıda Mühendisliği Ana Bilim Dalı, Yüksek Lisans Tezi, 73 sy.

Cin P, Gezer C 2017. Fonksiyonel Bir Besin Olarak Turunçgiller ve Metabolik Sendrom İlişkisi. Food and Health 3(2):49-58.

Çoksever E 2009. Farklı Oranlarda Turunç Albedosu İlavesinin Sucuk Kalitesi Üzerine Etkisi. Selçuk Üniversitesi Fen Bilimleri Enstitüsü Gıda Mühendisliği Ana Bilim Dalı, Yüksek Lisans Tezi, 99 sy.

Demir M K, Elgün A, Bilgiçli N 2006. Sıvı Ferment Yöntemi ile Ekmek Üretiminde Kullanılan Maya (Saccharomyces cerevisae) Performansina Katkı Maddeleri ve Ortam Şartlarının Etkisi. Gıda 31(6):303-310.

Demirel H 2017. Farklı Turunçgillerden Elde Edilen Albedoların Bisküvi Üretiminde Kullanım İmkanları. Necmettin Erbakan Üniversitesi Fen Bilimleri Enstitüsü Gıda Mühendisliği Ana Bilim Dalı, Yüksek Lisans Tezi, 76 sy.

Demirel H, Demir M K 2018. Farklı Turunçgillerden Elde Edilen Albedoların Bisküvi Üretiminde Kullanımı. Gida 43(3):501-511.

Düzgüneş O, Kesici T, Kavuncu O, Gürbüz F 1987. Araştırma ve Deneme Metodları. Ankara Üniversitesi Ziraat Fakültesi Yayınları, Yayın No: 1021, Ankara, 381 sy.

Ekici L, Ercoşkun H 2007. Et Ürünlerinde Diyet Lif Kullanımı. Gıda Teknolojileri Elektronik Dergisi 1:83-90.

Elgün A, Ertugay Z 1995. Tahıl İşleme Teknolojisi. Atatürk Üniversitesi Ziraat Fakültesi Yayınları, Yayın No: 297 (2.Baskı), Erzurum, 481 sy.

Elgün A, Ertugay Z, Certel M, Kotancılar H G 2002. Tahıl ve Ürünlerinde Analitik Kalite Kontrolü ve Laboratuvar Uygulama Kllavuzu. Atatürk Üniversitesi Yayınları, Yayın No: 335, Ders Kitapları Serisi No: 82, Erzurum, 245sy.

Elgün A, Türker S, Bilgiçli N 2005. Tahıl ve Ürünlerinde Analitik Kalite Kontrolü. Selçuk Üniversitesi Ziraat Fakültesi Gıda Mühendisliği Bölümü Ders Notları, Konya, 112 sy.

Eyidemir E 2006. Kayısı Çekirdeği İlavesinin Eriştenin Bazı Kalite Kriterlerine Etkisi. İnönü Üniversitesi Fen Bilimleri Enstitüsü Gıda Mühendisliği Ana Bilim Dalı, Yüksek Lisans Tezi, 84 sy.

Farnworth E R, Lagace M, Couture R, Yaylayan V, Stewart B 2001. Thermal Processing, Storage Conditions, and The Composition and Physical Properties of Orange Juice. Food Research International 34(1):25-30.

Fernández-Ginés J, Navarro C, Sendra E, Sayas M, Fernández-López J, Pérez-Álvarez J 2001.
Colourimetric Characterization of Meat Emulsion Containing Albedo. 47th International Congress of Meat Science and Technology Vol II. pp. 162-163, Cracovia, Poland.

Francis F J 1998. Colour Analysis. (An Aspen Publishers: Maryland, Gaithersnurg, USA: Ed. Nielsen S S) 599-612.

Garcia-Estapa R M, Guerra-Hernandez E, GarciaVillanova B 1999. Phytic Acid Content in Milled Cereal Products and Breads. Food Research International 32:217-221.

Gorinstein S, Martín-Belloso O, Park Y S, Haruenkit R, Lojek A, Ĉ́žz M, Caspi A, Libman İ, Trakhtenberg S 2001. Comparison of Some Biochemical Characteristics of Different Citrus Fruits. Food Chemistry 74(3):309-315.

Gölükcü M, Toker R, Tokgöz H, Turgut D M 2015. Farklı Yöntemlerle Elde Edilen Turunç (Citrus aurantium L.) Kabuk Yağlarının Uçucu Yağ Bileşimleri. Derim 32(2):161-170.

Halaç E 2002. Gıda Kalitesi ve Gıda Mevzuatı ile İlgili Temel Kavramlar Işı̆̆ında Türk ve AB Gıda Mevzuatının Karşılaştırılması. Akdeniz İ̈BF Dergisi 4:107-131.

Harris P J, Ferguson L R 1999. Dietary Fibres May Protect or Enhance Carcinogenesis. Mutation Research/Genetic Toxicology and Environmental Mutagenesis 443(1-2):95-110.

Haug W, Lantzsch H J 1983. Sensitive Method for the Rapid Determination of Phytate in Cereals and Cereal Product. Journal of the Science of Food and Agriculture 34(12):1423-1426.

Kang H J, Chawla S P, Jo C, Kwon J H, Byun M W 2006. Studies on The Development of Functional Powder From Citrus Peel. Bioresearch Technology 97(4):614-620.

Kaya A 2018. Nohudun Erişte Kalitesine Etkisi. Harran Üniversitesi Fen Bilimleri Enstitüsü Gıda Mühendisliği Ana Bilim Dalı, Yüksek Lisans Tezi, 137 sy.

Kaygısız H, Aybak H Ç 2005. Narenciye Yetiştiriciliği. Hasad Yayıncilık, İstanbul, $224 \mathrm{sy.}$

Kotancılar G, Çelik İ, Ertugay Z 1995. Ekmeğin Besin Değeri ve Beslenmedeki Önemi. Atatürk Üniversitesi Ziraat Fakültesi Dergisi 26(3):431441.

Koubala B B, Mbome L I, Kansci G, Mbiapo F T, Crepeau M J, Thibault J F, Ralet M C 2008. Physicochemical Properties of Pectins From Ambarella Peels Obtained Using Different Extraction Conditions. Food Chemistry 106(3):1202-1207.

Liu Y, Heying E, Tanumihardjo S A 2012. History, Global Distribution, and Nutritional Importance of Citrus Fruits. Comprehensive Revievs in Food Science and Food Safety 11(6):530-545.

Mendilcioğlu K 1996. Subtropik İklim Meyveleri (Turunçgiller). E.Ü. Ziraat Fakültesi Ofset 
Basımevi, Bornova, İzmir, 93 sy.

Meral R, Doğan İ S 2009. Fonksiyonel Öneme Sahip Doğal Bileşenlerin Unlu Mamüllerin Üretiminde Kullanımı. Gida Dergisi 34(3):193-198.

Mete M, Altıner D D 2018. Eriştenin Farklı Un Katkıları ile Zenginleştirilmesi. Akademik Gıda 16(2):252-256.

Miller R A 2011. Increased Yield of Bread Containing Citrus Peel Fiber. Cereal Chemistry 88(2):174-178.

Ocen D, Xu X 2013. Effect of Citrus Orange (Citrus sinensis) By-Product Dietary Fiber Preparations on The Quality Characteristics of Frozen Dough Bread. American Journal of Food Technology 8(1):43-53.

Qureshi A, Ainee A, Nadeem M, Munir M, Qureshi T M, Jabbar S 2017, Effect of Grape Fruit Albedo Powder on The Physicochemical and Sensory Attributes of Fruit Cake. Pakistan Journal of Agricultural Research 30(2):185-193.

Rouseff R L, Nagy S 1994. Health and Nutritional Benefits of Citrus Fruit Components. Food Techology 48:125-132.

Schröder R, Clark C J, Sharrock K, Hallett I C, MacRae E A 2004. Pectins From The Albedo of Immature Lemon Fruitlets Have High Water Binding Capacity. Journal of Plant Physiology 161(4):371-379.

Sinclair W B 1984. The Biochemistry and Physiology of the Lemon and Other Citrus Fruits. Division of Agriculture and Natural Resources, University of California Publication, California, USA, 946 sy.

Şat I G, Keleş F 2004. Fitik Asit ve Beslenmeye Etkisi. Gida 29(6):405-409.

Şimşek A G N, Taştan H, Dönmez B 2017. Fonksiyonel Gıdaların Yararlı Bulunması ve Kullanım Sıklı̆̆ İlişkisi, 1. Uluslararası Turizmin Geleceği Kongresi: İnovasyon, Girişimcilik ve
Sürdürebilirlik Kongresi (Futourism 2017) 28-30 Eylül 2017, Mersin, Türkiye.

Tokgöz H， Gölükcü M 2009. Turunç (Citrus aurantium) Meyvelerinin Değerlendirilme Yöntemleri ve İnsan Sağllğ̣ Üzerine Etkileri. Hasad Gida 284:44-48.

Turhan İ, Tetik N, Karhan M 2006. Turunçgil Kabuk Yağlarının Elde Edilmesi ve Gida Endüstrisinde Kullanımı. Gıda Teknolojileri Elektronik Dergisi 3:71-77.

TÜİK 2016. Bitkisel Üretim İstatistikleri, İstatistiksel Tablolar: Turunçgiller. http://www.tuik.gov.tr

Türksoy S 2011. Meyve ve Sebze Lif Konsantreleri İlavesinin Hamurun Reolojik Özellikleri ve Bisküvi Kalitesine Etkileri. Ankara Üniversitesi Fen Bilimleri Enstitüsü Gıda Mühendisliği Ana Bilim Dall, Doktora Tezi, 118 sy.

Uchoa A M A, Correia da Costa J M, Maia G A, Meira T R, Sousa P H M, Brasil I M 2009. Formulation and Physicochemical and Sensorial Evaluation of Biscuit-Type Cookies Supplemented with Fruit Powders. Plant Foods for Human Nutrition 64:153159.

Uysal L H 2005. Farkl Kaynaklardan Elde Edilen Besinsel Liflerin Bisküvi Kalitesi Üzerine Etkilerinin Karşılaştırılması. Selçuk Üniversitesi Fen Bilimleri Enstitüsü Gıda Mühendisliği Ana Bilim Dalı, Yüksek Lisans Tezi, 80 sy.

Yılmaz E 2002. Turunçgil Meyvelerinin İnsan Sağlığına Etkileri. Gıda Mühendisliği Dergisi 13:47-52.

Yllmaz Y 2019. Yer Bademi Sütü (Horchata) Yan Ürünlerinin Ekmek Üretiminde Değerlendirilmesi Üzerine Bir Çalışma. Hacettepe Üniversitesi Fen Bilimleri Enstitüsü Gıda Mühendisliği Ana Bilim Dalı, Yüksek Lisans Tezi, 140 sy. 